UDC $541.18+66.097 .3$

N.V. Nikolenko ${ }^{a}$, Yu.V. Kalashnikov ${ }^{b}$, A.O. Kostyniuk ${ }^{c}$, A.Yu. Poloz ${ }^{d}$, E.V. Aksenenko ${ }^{e}$

\title{
DIFFERENCE IN ADSORPTION PROPERTIES OF Fe(III), Mo(VI) OXIDES AND Fe(III) MOLYBDATE AS A CAUSE OF HIGH SELECTIVITY OF METHANOL OXIDATION ON IRON MOLYBDATE CATALYST
}

a Ukrainian State University of Chemical Technology, Dnipro, Ukraine

b Trespa International B.V., Weert, Netherlands

c National Institute of Chemistry, Ljubljana, Slovenia

d New Technologies Ltd., Dnipro, Ukraine

e Dumansky Institute of Colloid Chemistry and Water Chemistry, Kyiv, Ukraine

\begin{abstract}
The adsorption of a number of organic acids and bases from aqueous and methanol solutions was studied under static conditions at room temperature. It was shown that the organic compounds are adsorbed on $\mathrm{Fe}$ (III) and Mo(VI) oxides and $\mathrm{Fe}$ (III) molybdate due to the formation of the surface hydrogen bonds. The possibility of the adsorption by means of a donor-acceptor interaction of the organic compounds with the surface cations $\mathrm{Fe}^{3+}$ was not detected. It was shown that the adsorption energies of organic bases are linearly correlated with the effective charge of nitrogen atoms and their adsorbability changes in the following range: $\mathrm{Fe}_{2} \mathrm{O}_{3}>\mathrm{MoO}_{3}>\mathrm{Fe}_{2}\left(\mathrm{MoO}_{4}\right)_{3}$. An explanation of these correlations was proposed based on the concept of the domination of electrostatic interactions. Heterogeneous-catalytic oxidation of methanol and formaldehyde was proposed to consider assuming two forms of adsorption of their molecules: via binding of oxygen atoms with Lewis acid sites, or via the interaction of carbon and hydrogen atoms of the $\mathrm{C}-\mathrm{H}$ bonds with Lewis basic centers of a catalyst. It was concluded that the selectivity of the iron molybdate catalyst in the partial oxidation of methanol can be caused by low adsorbability of intermediate products of the methanol oxidation reaction on the catalyst surface.
\end{abstract}

Keywords: adsorption, effective charge, molybdenum oxide, ferric oxide, iron molybdate.

DOI: $10.32434 / 0321-4095-2019-124-3-35-45$

\section{Introduction}

A mixture of iron (III) molybdate with molybdenum (VI) oxide at a molar ratio $\mathrm{Mo} / \mathrm{Fe}=2-$ 5 is a well-known iron molybdate catalyst used for the oxidation of methanol to formaldehyde. Despite the industrial success, the work in the field of a further improvement of iron molybdate catalysts is still in progress [1-4]. It was shown that the molybdenum (VI) and iron (III) oxides in their individual state exhibit a relatively low catalytic selectivity towards the reaction of the partial oxidation of methanol. The sintering of these oxides with the formation of $\mathrm{Fe}_{2}\left(\mathrm{MoO}_{4}\right)_{3}$ structure promotes a significant increase in the catalytic activity and the selectivity of the oxidation of methanol. The reasons for this synergism of the catalytic properties of $\mathrm{Fe}$ (III) and $\mathrm{Mo}(\mathrm{VI})$ oxides mixture are still being discussed
[5-7].

In our opinion, it is necessary to compare the adsorption properties of iron and molybdenum oxides to determine the mechanism of an increased catalytic activity. The adsorption stage in a heterogeneous catalytic process determines the surface concentration of the transformed agent, and thus can affect the rate of the overall process. Therefore, the differences in adsorption properties of $\mathrm{Fe}(\mathrm{III}), \mathrm{Mo}(\mathrm{VI})$ oxides and $\mathrm{Fe}$ (III) molybdate can be a principal cause of differences in their catalytic activity. In this work, the adsorption properties of $\mathrm{Fe}(\mathrm{III})$, Mo(VI) oxides and $\mathrm{Fe}(\mathrm{III})$ molybdate were investigated at a temperature below the ignition temperature of the iron molybdate catalyst, when the homolytic dissociation of the bonds $\mathrm{Me}-\mathrm{O}$ cannot occur on their surfaces and does not lead to the formation of

(C) N.V. Nikolenko, Yu.V. Kalashnikov, A.O. Kostyniuk, A.Yu. Poloz, E.V. Aksenenko, 2019

Difference in adsorption properties of $\mathrm{Fe}(I I I), \mathrm{Mo}(\mathrm{VI})$ oxides and $\mathrm{Fe}(\mathrm{III})$ molybdate as a cause of high selectivity of methanol oxidation on iron molybdate catalyst 
highly reactive radical oxygen species.

The organic acids and bases were used as test reagents, which characterized the adsorption properties of the polar solids [8-10]. The studies of the adsorption of such compounds allow characterizing not only the acid-base properties, but also the redox properties of the adsorbent, and identifying the dominant force of the adsorption interaction. Previously, we showed that the adsorption of organic acids and bases can be considered according to two approaches: chargecontrolled adsorption, when the adsorption is mainly determined by the atom charges of the adsorbate and adsorbent; and frontier-controlled adsorption, when the frontier orbital energies of the adsorbate and adsorbent are close to each other. At present, it is reliably known that charge-controlled adsorption is characteristic of wide-zone polar adsorbents. Adsorption of polar organic compounds on these adsorbents is caused by the steric accessibility and by the values of the highest effective charges of atoms taking part in forming surface hydrogen or coordination bonds.

If we take into account that $\mathrm{Fe}$ (III) and $\mathrm{Mo}(\mathrm{VI})$ ions have unfilled d-electron levels, we can suggest the possibility of adsorption of the organic acids or bases on oxides through displacing their surface HOions with the formation of donor-acceptor bonds. For example, the possibility of the replacement of $\mathrm{HO}$-ions in the coordination sphere of $\mathrm{Fe}$ (III) was considered by authors [11], where the adsorption of the phosphate ions on $\alpha$-ferric oxide was studied. It was found that the adsorption of the phosphate ions was accompanied by a partial (non-equivalent) absorption of $\mathrm{H}^{+}$ions (or the separation of $\mathrm{HO}^{-}$ ions). To explain these data, the following equations have been proposed:

$$
\begin{gathered}
=\mathrm{FeOH}_{2}{ }^{+}+\mathrm{H}_{2} \mathrm{PO}_{4}^{-} \rightarrow=\mathrm{FeH}_{2} \mathrm{PO}_{4}+\mathrm{H}_{2} \mathrm{O}, \\
=\mathrm{FeOH}+\mathrm{H}_{2} \mathrm{PO}_{4}^{-} \rightarrow=\mathrm{FeH}_{2} \mathrm{PO}_{4}+\mathrm{HO}^{-} .
\end{gathered}
$$

However, the authors [11] have not taken into account that some portion of the acid is consumed in the processes of the hydrolysis of phosphate ion. Also, the change of $\mathrm{pH}$ during the establishment of hydrolytic equilibrium in the solution and on the surface of the hematite should be taken into consideration. In relation to this fact, the assumption about the possibility of the HO-ions displacement from the surface of the ferric oxide requires additional studies.

It is known that the coordination properties of $\mathrm{Fe}$ (III) ion are more similar to properties of cations with the electron shells $\mathrm{s}^{2}$ and $\mathrm{s}^{2} \mathrm{p}^{6}$ rather to those of d-elements. The stability of the cations' complexes with $s^{2}$ and $s^{2} p^{6}$ shells depends on the electrostatic characteristics of the ligand and the central cation: the higher the charge and the smaller the radius of these particles, the higher is the stability. Therefore, the most stable complexes are formed by the ligands with the highest charge density on the donor atoms. For example, the affinity to such cations of negatively charged oxygen atoms is higher than the affinity of nitrogen-bearing ligands. We believe that similar behavior could be observed also for the adsorption on ferric and molybdenum oxides.

To verify this assumption, the adsorption of some organic acids and bases on $\alpha-\mathrm{Fe}_{2} \mathrm{O}_{3}, \alpha-\mathrm{MoO}_{3}$ and $\mathrm{Fe}_{2}\left(\mathrm{MoO}_{4}\right)_{3}$ was studied. The energy of adsorption interaction was calculated based on the adsorption isotherms. To determine the nature of the adsorption interaction, the material balance of adsorption was calculated, and spectroscopic studies of adsorbed compounds were used. Also, the possibility of correlations between the energies of adsorption and effective charges of polar atoms of the organic compounds was considered. Based on these data, it was proposed to consider the selectivity of the iron molybdate catalyst as a result of the difference between adsorption properties of the oxides $\mathrm{Fe}(\mathrm{III}), \mathrm{Mo}(\mathrm{VI})$ and $\mathrm{Fe}(\mathrm{III})$ molybdate.

\section{Experimental}

Oxides preparation and characterization

The oxides $\alpha-\mathrm{MoO}_{3}, \alpha-\mathrm{Fe}_{2} \mathrm{O}_{3}$ and molybdate $\mathrm{Fe}_{2}\left(\mathrm{MoO}_{4}\right)_{3}$ were used as adsorbents. For their preparation, reagent grade $\mathrm{Fe}\left(\mathrm{NO}_{3}\right)_{3} \cdot 9 \mathrm{H}_{2} \mathrm{O}$, $\left(\mathrm{NH}_{4}\right)_{6} \mathrm{Mo}_{7} \mathrm{O}_{24} \cdot 4 \mathrm{H}_{2} \mathrm{O}, \mathrm{HNO}_{3}, \mathrm{NH}_{4} \mathrm{OH}$ and distilled water were used.

The preparation methods of $\mathrm{Fe}_{2} \mathrm{O}_{3}$ and $\mathrm{MoO}_{3}$ were quite similar. At the initial stage, gradual mixing of either concentrated solutions of $\mathrm{Fe}$ (III) nitrate and ammonium hydroxide at the $\mathrm{pH}$ of $9-10$ or concentrated solutions of ammonium heptamolybdate and nitric acid at the $\mathrm{pH}$ of 1-2 was performed at room temperature at a continuous stirring using a propeller stirrer. The resulting slurry was filtered using a Buchner funnel, then the obtained sediment was dried in a vacuum desiccator and calcined at $500^{\circ} \mathrm{C}$ for $8 \mathrm{~h}$ to remove $\mathrm{NO}_{3}{ }^{-}$and $\mathrm{NH}_{4}{ }^{+}$ impurity ions. The structures of $\alpha-\mathrm{Fe}_{2} \mathrm{O}_{3}$ and $\alpha-\mathrm{MoO}_{3}$ were verified by $\mathrm{X}$-ray diffraction analysis.

$\mathrm{Fe}_{2}\left(\mathrm{MoO}_{4}\right)_{3}$ was prepared by drop-wise adding of concentrated solution of $\mathrm{Fe}(\mathrm{III})$ nitrate to a hot $\left(\sim 70^{\circ} \mathrm{C}\right)$ solution of ammonium heptamolybdate acidified with nitric acid to $\mathrm{pH} 2$ with continuous stirring. The resulting slurry was evaporated, oven dried at $110^{\circ} \mathrm{C}$ and then calcined at $500^{\circ} \mathrm{C}$ for $48 \mathrm{~h}$. 
The structure of $\mathrm{Fe}_{2}\left(\mathrm{MoO}_{4}\right)_{3}$ was verified by X-ray diffraction analysis.

\section{Methods of adsorption measurements}

Aromatic acids, alcohols, amines and heterocyclic nitrogen-containing compounds were used as adsorbates. Before using, all compounds were purified by distillation or recrystallization. The choice of aromatic and heterocyclic compounds is caused by their rapid quantitative determination in aqueous solution by spectrophotometry.

The adsorption was studied by static method. Weighed amounts of adsorbent $(0.50-1.00 \mathrm{~g})$ were added to precisely measured volumes (10.00$20.00 \mathrm{~cm}^{3}$ ) of the organic compounds solution. A supporting electrolyte $(0.1 \mathrm{M} \mathrm{KCl})$ was added to the solutions to maintain constant ionic strength. The suspensions were kept to stand for $24 \mathrm{~h}$ with periodic stirring and then they were centrifuged. The concentrations of the solutions were determined by spectrophotometry method using Specord M40 with corrections for the evaporation of highly volatile compounds being made via blank experiments. Values of adsorption were calculated as $\left(\mathrm{C}_{0}-\mathrm{C}\right) \mathrm{V} / \mathrm{m}$, where $\mathrm{C}_{0}$ and $\mathrm{C}$ are the initial and equilibrium concentrations of organic compounds in solution, respectively. All measurements were performed at $18 \pm 2^{\circ} \mathrm{C}$. Reproducibility of adsorption measurements was verified by experiments repetition. It was found that the highest possible relative standard deviations for three repeated measurements did not exceed the following values: $14.5 \%$ for the values of adsorption and $3.5 \%$ for the free energies of adsorption.

\section{Study on adsorption material balance}

The calculation was based on consideration of equilibriums of $\mathrm{H}^{+}, \mathrm{HO}^{-}$and organic compounds adsorption on $\equiv \mathrm{MeOH}$ groups of hydrated oxide surface. The surface of oxides is known to acquire a charge due to dissociation of surface HO-groups or adsorption of $\mathrm{H}^{+}$and $\mathrm{HO}^{-}$ions (these two models are thermodynamically indistinguishable):

$\equiv \mathrm{MeOH}+\mathrm{H}^{+} \leftrightarrow \equiv \mathrm{MeOH}_{2}{ }^{+}$,

$\equiv \mathrm{MeOH}+\mathrm{HO}^{-} \leftrightarrow \equiv \mathrm{MeO}^{-}+\mathrm{H}_{2} \mathrm{O}$.

Adsorption of organic molecules HAn on $\equiv \mathrm{MeOH}$ groups without release of $\mathrm{H}^{+}$and $\mathrm{HO}^{-}$ions can be described by the following equations:

$\equiv \mathrm{MeOH}+\mathrm{HAn} \leftrightarrow \equiv \mathrm{MeOH} \cdots \mathrm{AnH}$

$\equiv \mathrm{MeOH}+\mathrm{HAn} \leftrightarrow \equiv \mathrm{MeO}(\mathrm{H}) \cdots \mathrm{HAn}$,

and, with a release of $\mathrm{H}^{+}$and $\mathrm{HO}^{-}$ions, by the following equations:

$$
\begin{aligned}
& \equiv \mathrm{MeOH}+\mathrm{HAn} \leftrightarrow \equiv \mathrm{MeOHAn}^{-}+\mathrm{H}^{+}, \\
& \equiv \mathrm{MeOH}+\mathrm{HAn} \leftrightarrow \equiv \mathrm{MeAn}+\mathrm{H}_{2} \mathrm{O} .
\end{aligned}
$$

In general, the adsorption of organic acid anions can also be described as the formation of hydrogen, ionic, or coordination bonds:

$$
\begin{aligned}
& \equiv \mathrm{MeOH}+\mathrm{An}^{-} \leftrightarrow \equiv \mathrm{MeAn}+\mathrm{HO}^{-}, \\
& \equiv \mathrm{MeOH}+\mathrm{An}^{-} \leftrightarrow \equiv \mathrm{MeOH} \cdots \mathrm{An}^{-} .
\end{aligned}
$$

Similar expressions can also be derived for the surface $\equiv \mathrm{MeO}^{-}$and $\equiv \mathrm{MeOH}_{2}{ }^{+}$groups.

Note that the ratio between the amounts of $\mathrm{H}^{+}$ and $\mathrm{HO}^{-}$ions in a solution is determined by the equilibrium:

$\mathrm{H}^{+}+\mathrm{HO}^{-} \leftrightarrow \mathrm{H}_{2} \mathrm{O}$

and therefore possible variations in the acidity of solutions during adsorption, for example, by Eqs. (5) and (7), do not reflect absolute amounts of released $\mathrm{H}^{+}$and $\mathrm{HO}^{-}$ions, but only their relative excesses. Dissociation of acid molecules should also be taken into account in addition to acid-based equilibria mentioned above:

$\mathrm{HAn} \leftrightarrow \mathrm{H}^{+}+\mathrm{An}^{-}$.

On the basis of Eqs. (1)-(10), we derived the equations of the material balance for the case $\mathrm{pH}<\mathrm{pH}_{0}$ (where $\mathrm{pH}_{0}$ is the point of zero charge). Assuming that the adsorption is accompanied by the substitution of $\mathrm{HO}^{-}$ions, the initial (in.) and equilibrium (eq.) amounts of $\mathrm{H}^{+}$and $\mathrm{HO}^{-}$ions could be related through the following equations:

$\mathrm{n}\left(\mathrm{H}^{+}\right)_{\mathrm{in}}-\mathrm{n}\left(\mathrm{H}^{+}\right)_{1}-\mathrm{n}\left(\mathrm{H}^{+}\right)_{9}+\mathrm{n}\left(\mathrm{H}^{+}\right)_{10}=\mathrm{n}\left(\mathrm{H}^{+}\right)_{\mathrm{eq}}$,

$\mathrm{n}\left(\mathrm{HO}^{-}\right)_{\mathrm{in}}+\mathrm{n}\left(\mathrm{HO}^{-}\right)_{7}-\mathrm{n}\left(\mathrm{HO}^{-}\right)_{9}=\mathrm{n}\left(\mathrm{HO}^{-}\right)_{\mathrm{eq}}$,

where $\mathrm{n}$ is the molar amount of $\mathrm{H}^{+}$or $\mathrm{HO}^{-}$ions. Subscripts at $\mathrm{n}\left(\mathrm{H}^{+}\right)$and $\mathrm{n}\left(\mathrm{HO}^{-}\right)$correspond to the number of equations.

The amount of $\mathrm{HO}^{-}$ions adsorbed according to Eq. (2) is neglected in this case, because the fraction of the surface $\equiv \mathrm{MeO}^{-}$groups at $\mathrm{pH}<\mathrm{pH}_{0}$ is significantly smaller than that of $\equiv \mathrm{MeOH}_{2}{ }^{+}$and $\equiv \mathrm{MeOH}$ groups. According to Eq. (9), the value of $\mathrm{n}\left(\mathrm{H}^{+}\right)_{9}$ is equal to $\mathrm{n}\left(\mathrm{HO}^{-}\right)_{9}$ and therefore the combination of Eqs. (11) and (12) yields: 
$\mathrm{n}\left(\mathrm{HO}^{-}\right)=\Delta \mathrm{n}\left(\mathrm{HO}^{-}\right)+\Delta \mathrm{n}\left(\mathrm{H}^{+}\right)-\Gamma_{\mathrm{H}}{ }^{+}+\Delta \mathrm{C}_{\mathrm{HAn}}$,

where $\mathrm{n}\left(\mathrm{HO}^{-}\right)=\mathrm{n}\left(\mathrm{HO}^{-}\right)_{7}$ is the amount of $\mathrm{HO}^{-}$ions released according to Eq. (7), $\Delta \mathrm{n}\left(\mathrm{H}^{+}\right)=\mathrm{n}\left(\mathrm{H}^{+}\right)_{\text {in }}-$ $\mathrm{n}\left(\mathrm{H}^{+}\right)_{\mathrm{eq}}, \Delta \mathrm{n}\left(\mathrm{HO}^{-}\right)=\mathrm{n}\left(\mathrm{HO}^{-}\right)_{\mathrm{eq}}-\mathrm{n}\left(\mathrm{HO}^{-}\right)_{\mathrm{m}}, \Gamma_{\mathrm{H}^{+}}=\mathrm{n}\left(\mathrm{H}^{+}\right)_{1}$ is the molar amount of $\mathrm{H}^{+}$ions adsorbed by oxide according to Eq. (1), and $\Delta \mathrm{C}_{\mathrm{HAn}} \equiv \mathrm{n}\left(\mathrm{H}^{+}\right)_{10}$ is the amount of HAn molecules dissociated according to Eq. (10). All components of these equations are expressed in moles.

Equation for the calculation of the amount of $\mathrm{H}^{+}$ions released in adsorption according to Eq. (5) can be obtained similarly:

$\mathrm{n}\left(\mathrm{H}^{+}\right)=\Gamma_{\mathrm{H}}{ }^{+}-\Delta \mathrm{n}\left(\mathrm{HO}^{-}\right)-\Delta \mathrm{n}\left(\mathrm{H}^{+}\right)-\Delta \mathrm{C}_{\mathrm{HAn}}$.

Hence, knowing $\mathrm{pH}_{\mathrm{in}}$ and $\mathrm{pH}_{\mathrm{eq}}$ and determining $\Gamma_{\mathrm{H}}{ }^{+}$(from the data on potentiometric titration of oxide) and $\Delta \mathrm{C}_{\mathrm{HAn}}$ (from the data on the initial and equilibrium values of concentration of acid in a solution), we can calculate the amount of $\mathrm{HO}^{-}$and $\mathrm{H}^{+}$ions that can be released in adsorption.

\section{Results and discussion}

Adsorption of organic acids and bases from aqueous solutions

The studies of the adsorption of organic acids and bases from aqueous solutions on $\mathrm{Fe}_{2} \mathrm{O}_{3}$ showed that the carboxylic aromatic acids (benzoic, n-nitrobenzoic and 3,5-dinitrobenzoic) have the highest surface activity. The quinolones, pyridines and aromatic amines are adsorbed to a lower extent. Absorption was not found for benzamide, indole, phenol, pyrocatechol, resorcinol and 1-naphthol. These data show significant difference between the

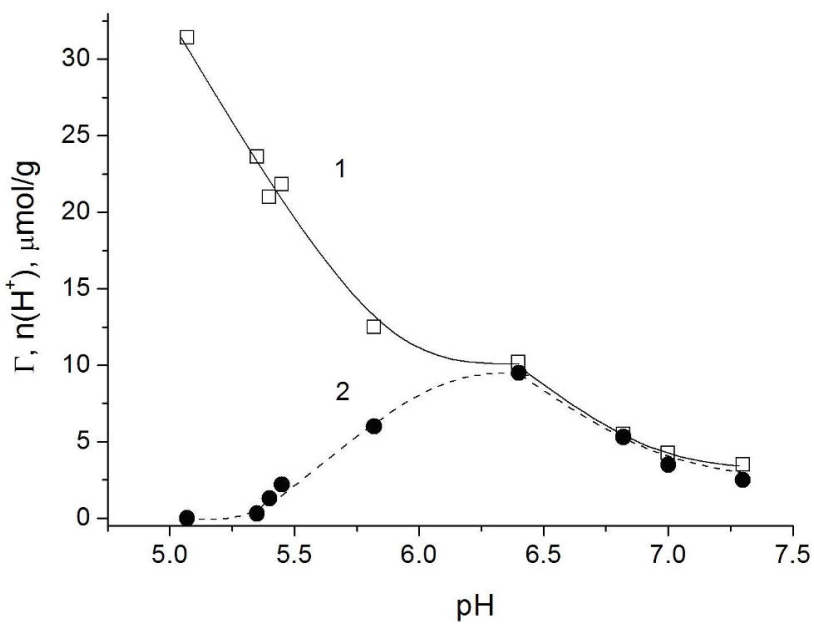

Fig. 1. Dependences of the value of adsorption of benzoic acid on $\alpha-\mathrm{Fe}_{2} \mathrm{O}_{3}(1)$ and the amount of $\mathrm{H}^{+}$ions released in the adsorption (2) on the equilibrium value of solution $\mathrm{pH}$ surface properties of the ferric oxide and coordination properties of $\mathrm{Fe}(\mathrm{III})$ cation: aromatic alcohols are not adsorbed on the oxide stronger than nitrogenbearing compounds. So far as the adsorbed molecule must displace $\mathrm{HO}$-ion from coordination sphere of $\mathrm{Fe}$ (III) for the interaction with its d-orbitals, it can be suggested that only anions of carboxylic acids are capable to compete with HO-ions. To check this hypothesis, the adsorption of benzoic acid at different acidity of solutions was studied.

Study of the adsorption of benzoic acid on $\alpha-\mathrm{Fe}_{2} \mathrm{O}_{3}$ as a function of the solution acidity showed that the values of adsorption $(\Gamma)$ decrease monotonically with an increase in $\mathrm{pH}$ (Fig. 1, curve 1).

Calculation of material balance shows that adsorption of benzoic acid is accompanied by the release of $\mathrm{H}^{+}$ions. In this case, with decreasing value of the adsorption of benzoic acid, the amount of the released $\mathrm{H}^{+}$ions first increases and then proportionally decreases only at $\mathrm{pH}>6.3$ (Fig. 1, curve 2). Taking into account that anions of acid dominate in the solution in the studied $\mathrm{pH}$ range and the values of the released $\mathrm{H}^{+}$ions at $\mathrm{pH}>6.5$ are coincident with the values of acid adsorption, we believe that the data obtained can be described by the following equilibria:

$$
\begin{aligned}
& =\mathrm{FeOH}_{2}{ }^{+}+\mathrm{An}^{-} \leftrightarrow=\mathrm{FeOH} \cdots \mathrm{An}^{-}+\mathrm{H}^{+}, \\
& =\mathrm{FeOH}_{2}{ }^{+}+\mathrm{An}^{-} \leftrightarrow=\mathrm{FeO}^{-} \cdots \mathrm{HAn}+\mathrm{H}^{+} .
\end{aligned}
$$

The fact of unconformity of the values of the released $\mathrm{H}^{+}$ions and acid adsorption at $\mathrm{pH}_{\mathrm{eq}}<6$ can be explaiedn by the spending of released $\mathrm{H}^{+}$ions in the following reaction:

$$
\mathrm{Fe}_{2} \mathrm{O}_{3}+6 \mathrm{H}^{+} \rightarrow 2 \mathrm{Fe}^{3+}+3 \mathrm{H}_{2} \mathrm{O} \text {. }
$$

Thus the material balance of the adsorption of the organic substances and the potential-determining ions $\mathrm{H}^{+}$and $\mathrm{HO}^{-}$has shown that the adsorption centers of the ferric oxide surface for the benzoic acid anions are protonated hydroxide groups $=\mathrm{FeOH}_{2}{ }^{+}$. It can be assumed that the main reason that the group $=\mathrm{FeOH}_{2}{ }^{+}$acts as an adsorption center lies in its Coulomb interaction with the anion of the acid.

In order to verify the assumption that the Coulomb attraction determines the nature of the adsorption center, we studied the material balance of the adsorption of nonionic compound benzonitrile $\mathrm{C}_{6} \mathrm{H}_{5} \mathrm{CN}$ on $\alpha-\mathrm{Fe}_{2} \mathrm{O}_{3}$. The molecules of benzonitrile do not undergo the dissociation and the protonation in aqueous solutions. The results obtained by the 


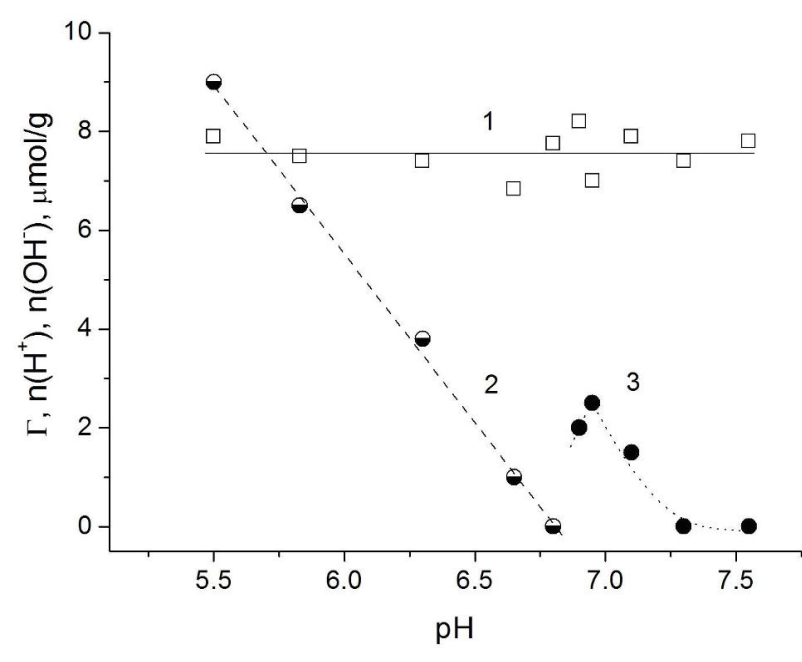

Fig. 2. Dependences of the value of adsorption of benzonitrile on $\alpha-\mathrm{Fe}_{2} \mathrm{O}_{3}(1)$, the amount of $\mathrm{HO}^{-}$ions released in the adsorption (2) and the amount of released $\mathrm{H}^{+}$ions (3) on the equilibrium value of solution $\mathrm{pH}$

adsorption measurements, potentiometric measurements and calculations of material balance for benzonitrile adsorption on $\alpha-\mathrm{Fe}_{2} \mathrm{O}_{3}$ are shown in Fig. 2.

It was found that the adsorption of non-ionic compound on oxide is accompanied by the release of both $\mathrm{HO}^{-}$ions (Fig. 2, curve 2) and $\mathrm{H}^{+}$ions (curve 3). At first sight, the results of material balance calculations for the adsorption of benzonitrile and benzoic acid are different. Adsorption of benzonitrile at $\mathrm{pH}<6.6$ is accompanied by the release of $\mathrm{HO}^{-}$ ions (Fig. 2, curve 2). With increasing value of the solution $\mathrm{pH}$, the amount of the released $\mathrm{HO}^{-}$ions monotonically increases and at $\mathrm{pH}>6.6$ adsorption of benzonitrile is accompanied by relatively small release of $\mathrm{H}^{+}$ions (Fig. 2, curve 3). It is necessary to note that all data at $\mathrm{pH}<6.6$ were obtained for solutions with initial $\mathrm{pH}$ below $\sim 4$, when ferric oxide can partially dissolve. The amount of $\mathrm{H}^{+}$ions consumed in this reaction can be identical to the amount of the released $\mathrm{HO}^{-}$ions because dissolution process was not taken into account in Eqs. (13) and (14). In our opinion, this conclusion is well conformed to the data of the material balance examination of the adsorption of benzoic acid on ferric oxide. The point is that the adsorption of benzoic acid is accompanied by the release of such amount of $\mathrm{H}^{+}$ions which is dominate over the amount of $\mathrm{H}^{+}$ions consumed in the reaction with $\mathrm{Fe}_{2} \mathrm{O}_{3}$.

More correct conclusions about the mechanism of adsorption can be drawn on the basis of the material balance data at $\mathrm{pH}_{\mathrm{in}}>4$, when the dissolution of oxide is not observed. Figure 2 (curve 1) shows that the value of benzonitrile adsorption virtually does not depend on solutions $\mathrm{pH}$ and almost twice dominates above the amount of the released $\mathrm{H}^{+}$ions.

Therefore, it can be concluded that the benzonitrile molecules in solutions with $\mathrm{pH}<\mathrm{pH}_{0}$ (where $\mathrm{pH}_{0}$ 7.3) are adsorbed simultaneously both on $=\mathrm{FeOH}_{2}{ }^{+}$and $=\mathrm{FeOH}$ groups of the oxide:

$$
\begin{gathered}
=\mathrm{FeOH}+\mathrm{C}_{6} \mathrm{H}_{5} \mathrm{CN} \leftrightarrow=\mathrm{FeOH} \cdots \mathrm{NCC}_{6} \mathrm{H}_{5}, \\
=\mathrm{FeOH}_{2}{ }^{+}+\mathrm{C}_{6} \mathrm{H}_{5} \mathrm{CN} \leftrightarrow=\mathrm{FeOH} \cdots \mathrm{NCC}_{6} \mathrm{H}_{5}+\mathrm{H}^{+} .
\end{gathered}
$$

The UV spectra also give evidence of the fact that benzoic acid and benzonitrile cannot displace the $\mathrm{HO}^{-}$ions in $=\mathrm{FeOH}$ and form the donoracceptor bond with $\mathrm{Fe}^{3+}$ ions of oxide surface. It was found that the spectra of all studied organic compounds adsorbed on $\mathrm{Fe}_{2} \mathrm{O}_{3}$ practically coincide with their spectra recorded both in water solutions and also on the surface of silica and alumina.

Thus it can be concluded that benzoic acid adsorbs from aqueous solutions mainly on $=\mathrm{FeOH}_{2}{ }^{+}$ groups, and benzonitrile adsorbs mainly on $=\mathrm{FeOH}$ groups. The results of material balance calculations showed that anions and molecules of aromatic acid and nitrile can compete with water molecules and be absorbed on $\mathrm{Fe}_{2} \mathrm{O}_{3}$ by means of hydrogen bonds and cannot compete with surface $\mathrm{HO}^{-}$ions combined in complex with $\mathrm{Fe}^{3+}$ ions.

From the point of view of charge-controlled model of adsorption $[8,10]$, the difference between the values of effective charges of oxygen and hydrogen atoms in surface $\mathrm{HO}$-groups of oxides and inconstancy of their quantity on surface are the main factors governing the selectivity of organic compounds adsorption on oxides.

It is unfortunately impossible to study the adsorption of organic compounds on $\mathrm{MoO}_{3}$ and $\mathrm{Fe}_{2}\left(\mathrm{MoO}_{4}\right)_{3}$ by the material balance method based on measurements of the acidity of solutions. The fact is that the study of the adsorption of organic compounds on molybdenum oxide and ferrum molybdate showed that the acidity of aqueous solutions quickly changes. For example, with sample weights of $1 \mathrm{~g}$ and volume of solution $20 \mathrm{~mL}$, the acidity changed to $\mathrm{pH} 3.8$ and $\mathrm{pH} 2.6$ for $\mathrm{Fe}_{2}\left(\mathrm{MoO}_{4}\right)_{3}$ and $\mathrm{MoO}_{3}$, respectivly. It is explained by the acidic nature of $\mathrm{MoO}_{3}$ and its ability to react with water to form molybdate ions. It is obvious that the solubility of iron molybdate should be increased due to hydrolysis of iron cations. It leads to the formation of the iron hydroxide film on surface of iron molybdate at $\mathrm{pH} 3.8$. Therefore, the study of the 
adsorption from aqueous solutions was performed only for molybdenum oxide. It was found that the adsorption isotherms of aromatic amines and pyridines on $\mathrm{MoO}_{3}$ have the shape of $\mathrm{H}$-type by the classification of Giles and co-authors. It indicates the chemical interaction of molybdate ions with organic bases in acidic environments. Therefore, in order to reduce the solubility of $\mathrm{MoO}_{3}$, further adsorption measurements were performed from methanol environments. solutions

Adsorption of organic bases from methanol

We studied the adsorption isotherms of eight organic bases (they are listed in Table) from their methanol solutions to compare the adsorption properties of the ferric and molybdenum oxides with those of iron (III) molybdate. It was found that all adsorption isotherms have the shape of Langmuir curve: the measured points are well fitted by the linear dependence in the coordinates «inverse adsorption vs. inverse concentration» within the studied concentration range $(1-10 \mathrm{mmol} / \mathrm{L})$. Free energies of adsorption of the organic compounds were calculated. The fact that the molecule of the organic base displaces one molecule of an alcohol at the adsorption on the oxide surface was taken into account by the equation: $\Delta \mathrm{G}=-\mathrm{RT} \cdot \ln 24.7 \mathrm{~B}$, where 24.7 is the molar concentration of methanol, B is the adsorption constant of Langmuir isotherm.

Fig. 3 illustrates the comparison of the adsorption energy of organic bases with the effective charges $\left(\mathrm{Q}_{\mathrm{N}}\right)$ of their nitrogen atoms for $\mathrm{Fe}_{2} \mathrm{O}_{3}, \mathrm{MoO}_{3}$ and $\mathrm{Fe}_{2}\left(\mathrm{MoO}_{4}\right)_{3}$. The values of atom effective charges (as a difference between charge of nuclear and effective number of electrons in the atom) were calculated by the iterative extended Huckel method, which differs from the usual RHM by the procedure of self-consistency for atomic charges of the molecule.

It follows from the data shown in Fig. 3 that

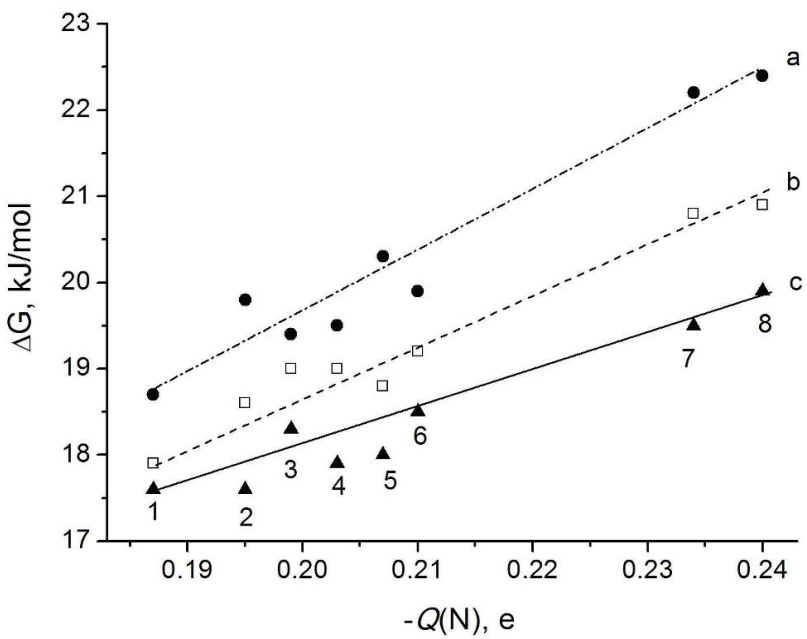

Fig. 3. Comparing the adsorption energies of organic bases for $\mathrm{Fe}_{2} \mathrm{O}_{3}(\mathrm{a}), \mathrm{MoO}_{3}$ (b) и $\mathrm{Fe}_{2}\left(\mathrm{MoO}_{4}\right)_{3}$ (c) with an effective charge of nitrogen atoms. The numbering of the points in the figure corresponds to the organic compounds shown in Table

the observed adsorption energy is linearly correlated with the effective charges of nitrogen atoms of the studied aromatic and heterocyclic amines.

According to the data given in Fig. 3, the magnitudes of adsorption energies for all studied compounds are regularly decreased in the following sequence: $\mathrm{Fe}_{2} \mathrm{O}_{3}, \mathrm{MoO}_{3}, \mathrm{Fe}_{2}\left(\mathrm{MoO}_{4}\right)_{3}$. Such a correlation can be explained if the adsorption of polar molecules in the polar adsorbent is considered to be the result of intermolecular interactions, predominantly through hydrogen bonds. It is known that total energy of molecular hydrogen-bonded complexes for the equilibrium interatomic distances often coincides with the electrostatic component of the interaction. Therefore, a linear dependence could exist between the adsorption energy and the largest effective charge of adsorbate [10].

The adsorption properties difference of $\mathrm{Fe}_{2} \mathrm{O}_{3}$, $\mathrm{MoO}_{3}$ and $\mathrm{Fe}_{2}\left(\mathrm{MoO}_{4}\right)_{3}$ can be explained by the

Effective charges of nitrogen atoms in aromatic and heterocyclic amines and the results of the determination of free energies of adsorption of organic compounds on $\mathrm{Fe}_{2}\left(\mathrm{MoO}_{4}\right)_{3}, \mathrm{Fe}_{2} \mathrm{O}_{3}$ and $\mathrm{MoO}_{3}$

\begin{tabular}{c|l|c|c|c|c}
\hline \multirow{2}{*}{ No. } & \multirow{2}{*}{ Organic compound } & \multirow{2}{*}{$-\mathrm{Q}(\mathrm{N}), \mathrm{e}$} & \multicolumn{3}{|c}{$-\Delta \mathrm{G}, \mathrm{kJ} / \mathrm{mol}$} \\
\cline { 4 - 6 } & & 0.187 & $\alpha-\mathrm{Fe}_{2} \mathrm{O}_{3}$ & $\alpha-\mathrm{MoO}_{3}$ & $\mathrm{Fe}_{2}\left(\mathrm{MoO}_{4}\right)_{3}$ \\
\hline 1 & 1-naphthylamine & 18.7 & 17.9 & 17.6 \\
\hline 2 & N,N-dimethylaniline & 0.195 & 19.8 & 18.6 & 17.6 \\
\hline 3 & m-toluidine & 0.199 & 19.4 & 19.0 & 18.3 \\
\hline 4 & pyridine-3-aldehyde & 0.203 & 19.5 & 19.0 & 17.9 \\
\hline 5 & aniline & 0.207 & 20.3 & 18.8 & 18.0 \\
\hline 6 & 2,8 -dimethylquinoline & 0.210 & 19.9 & 19.2 & 18.5 \\
\hline 7 & pyridine & 0.234 & 22.2 & 20.8 & 19.5 \\
\hline 8 & 2-picoline & 0.240 & 3 & 20.9 & 19.9 \\
\hline
\end{tabular}


difference in effective charges of hydrogen atoms of surface HO-groups which essentially are the adsorption centers for nitrogen containing molecules. As far as adsorption constants of organic bases are the highest for $\mathrm{Fe}_{2} \mathrm{O}_{3}$ and the smallest for $\mathrm{Fe}_{2}\left(\mathrm{MoO}_{4}\right)_{3}$, we can conclude that effective charges of hydrogen surface atoms in $\mathrm{HO}$-groups for adsorbents involved changes in the following sequence: $\mathrm{Q}_{\mathrm{H}}\left(\mathrm{Fe}_{2} \mathrm{O}_{3}\right)>$ $>\mathrm{Q}_{\mathrm{H}}\left(\mathrm{MoO}_{3}\right)>\mathrm{Q}_{\mathrm{H}}\left(\mathrm{Fe}_{2}\left(\mathrm{MoO}_{4}\right)_{3}\right)$.

It is necessary to note that the conclusion about the possibility of a linear correlation $\Delta \mathrm{G}\left(\mathrm{Q}_{\mathrm{N}}\right)$ is true first of all in those cases where the adsorbate molecule has only one atom with a sufficiently large charge and the influence of the electric multipole moments can be ignored. A more rigorous description of the relationship $\Delta \mathrm{G}\left(\mathrm{Q}_{\mathrm{N}}\right)$ requires consideration of the charge redistribution in the molecule under the influence of the electric field of the adsorbent. In addition to this fact, we also must take into account the statistical nature of adsorption and solvation processes: the probability of required orientation of adsorbate particle is determined by its size, inertial properties, etc.

\section{selectivity \\ Difference in adsorption as a basis of catalyst}

As follows from the previous subsection, the difference in the effective charges of hydrogen or oxygen atoms is determined by the difference in adsorption properties of the oxides surface. With respect to the oxidation of methanol to formaldehyde on iron molybdate catalysts, the difference in the effective charges of oxygen atoms for oxides $\mathrm{Fe}_{2} \mathrm{O}_{3}$ and $\mathrm{MoO}_{3}$ in comparison with $\mathrm{Fe}_{2}\left(\mathrm{MoO}_{4}\right)_{3}$ may determine the different magnitudes of the surface concentrations of formaldehyde as an intermediate product of methanol oxidation.

At present, a number of kinetic equations are proposed in the literature for the oxidation reaction of methanol by oxygen air. The applicability of these equations usually depends on the concentrations of methanol and oxygen involved in the experiments [12]. For the methanol/air mixtures with high concentration (up to 6.5\% methanol and 19\% oxygen), it was quite convincingly shown that the order of oxidation reaction with respect to oxygen is zero. At the same time, the reaction order with respect to methanol for model catalysts is less than 1 , while for industrial catalysts the reaction often is of the first order.

The explanations of these features are based on the assumption of selective adsorption of the reagents on different active centers of the catalyst surface. The supposition about the dominant character of this adsorption interaction still remains controversial in the literature.

Obviously, the structure of the formed adsorption compound should largely determine the structure of the transition state for methanol with active form of oxygen. Typically, the adsorption of molecules of methanol (as well as formaldehyde) on the oxide surface is considered to be the result of the interaction between the oxygen atom of organic molecules and the surface metal cations.

It is obvious that the total process rate can be controlled by the concentration of surface metal cations (Lewis acid centers) for the formation of $\equiv \mathrm{Me}-\mathrm{O}(\mathrm{H}) \mathrm{CH}_{3}$ surface compound and therefore the correlation between the oxidation rate and the energy of lattice oxygen is possible. This dependence exists, e.g., for cobalt, manganese, nickel and chromium oxides, which are characterized by low energy of oxygen binding $[13,14]$. The methanol molecule chemisorbed via oxygen is oxidized to formaldehyde, which then remains on the surface in the adsorbed state. Obviously, some fraction of the adsorbed formaldehyde is desorbed, while other fraction undergoes further oxidation to formic acid. In our opinion, such a reaction route which leads to the formation of adsorbed formaldehyde results in a high rate of the subsequent oxidation stage and is a main reason for the low selectivity of these oxides in the oxidation of the intermediate product.

In the case of oxides and metal molybdates with high energy of oxygen bonding, it could be supposed that the surface concentration of metal ions that have lost the oxygen and become available for the adsorption of oxygen-containing organic molecules is very small. Large excess of oxygen in the reaction mixture is another factor that contributes to the decrease of the concentration of free metal cations. In our opinion, among the possible mechanisms of adsorption of polar organic molecules in such conditions, the adsorption which involves the surface oxygen rather than the metal cation could be the prevalent one. As the binding with the lattice, oxygen is possible to interact only with positively charged atoms of adsorbed molecules, i.e. hydrogen and (or) carbon atoms, the molecule should be oriented with its carbon radical towards the surface. The contemporary concepts of the organic chemistry suggest that the most favorable for the process of oxidation of alcohol molecule is the nucleophilic attack by the reagent, e.g. by activated oxygen atom of the oxide surface. This attack is directed to the $\mathrm{C}-\mathrm{H}$ bond and the result of this interaction is the introduction of oxygen atom between the atoms of $\mathrm{C}-\mathrm{H}$ bond (Fig. 4).

The possibility of the formation of a transition 


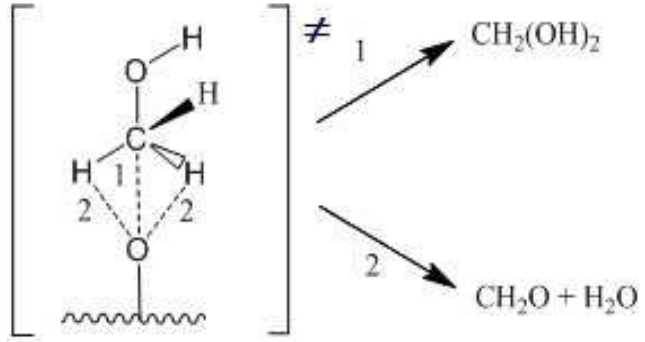

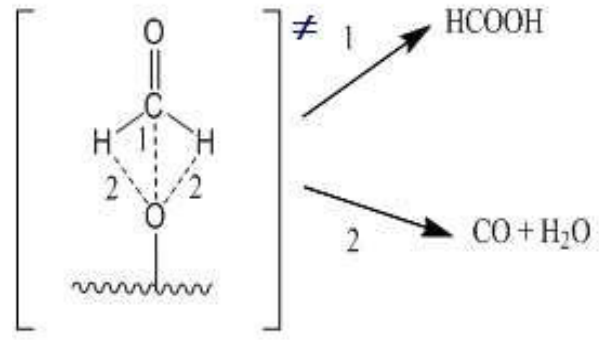

b

Fig. 4. Schematic representation of activated complexes of methanol (a) and formaldehyde (b) on the surface of the oxide catalyst

state of formaldehyde molecule with the chemisorbed or lattice oxygen on the surface of oxide molybdenum catalyst was studied by quantum chemical modeling [15]. It was shown that two ways of transformations of an activated complex are possible in the nucleophilic attack of a carbon atom: either the breakdown of the $\mathrm{C}-\mathrm{H}$ bonds with the formation of $\mathrm{CO}$ and the chemisorbed $\mathrm{H}_{2} \mathrm{O}$ molecule, or the weakening of one $\mathrm{C}-\mathrm{H}$ bond with the introduction of an oxygen atom and the formation of formic acid.

Thus the scheme of oxidation of methanol on iron molybdate catalyst can be presented as follows:

$$
\mathrm{CH}_{3} \mathrm{OH}_{\text {g.p. }} \stackrel{\mathrm{k}_{1}}{\underset{\mathrm{k}_{2}}{\longrightarrow}} \mathrm{CH}_{3} \mathrm{OH}_{\text {ads. }} \stackrel{\mathrm{k}_{3}}{\longrightarrow} \mathrm{CH}_{2} \mathrm{O}_{\text {g.p. }} \rightarrow
$$

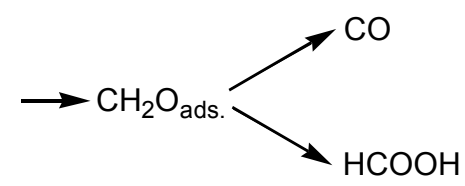

where $\mathrm{k}_{1}$ and $\mathrm{k}_{2}$ are the rate constant of adsorption and desorption, respectively; $\mathrm{k}_{3}$ is the rate constant for chemical transformation; g.p. and ads. denote gaseous phase and adsorbed state, respectively.

The kinetic equations for the first part of the considered scheme can be written in the following form:

$$
\begin{gathered}
\mathrm{r}_{\text {ads. }}=-\mathrm{k}_{1} \mathrm{C}_{\mathrm{CH}_{3} \mathrm{OH} \text {, g.p. }}\left(1-\theta_{\mathrm{CH}_{3} \mathrm{OH}}\right)+\mathrm{k}_{2} \theta_{\mathrm{CH}_{3} \mathrm{OH}}, \\
r_{\text {chem.t. }}=-\mathrm{k}_{3} \theta_{\mathrm{CH}_{3} \mathrm{OH}}^{*},
\end{gathered}
$$

where $\theta_{\mathrm{CH}_{3} \mathrm{OH}}^{*}=\alpha \theta_{\mathrm{CH}_{3} \mathrm{OH}}, \alpha$ is the fraction of alcohol molecules adsorbed with the participation of the oxygen of surface oxide with respect to the total amount of adsorbed methanol molecules. Since in the steady state $r_{\text {ads. }}=r_{\text {chem.t. }}$ (i.e. the rates of adsorption and chemical transformation are equal), the $\theta^{*}{ }_{\mathrm{CH} \text { OH }}$ value can be expressed via the rate constants of elementary stages and the concentration of methanol in the gaseous phase. Then, substituting the resulting expression into the formula for the chemical reaction rate, we obtain the following kinetic equation:

$$
\begin{aligned}
\mathrm{r}_{\text {chem.t. }}= & -\frac{\mathrm{k}_{3} \mathrm{C}_{\mathrm{CH}_{3} \mathrm{OH}, \text { g.p. }}}{\frac{\mathrm{k}_{3}}{\mathrm{k}_{1}}+\frac{\mathrm{k}_{2}}{\alpha \mathrm{k}_{1}}+\frac{1}{\alpha} \mathrm{C}_{\mathrm{CH}_{3} \mathrm{OH}, \mathrm{g} . \text { p. }}}= \\
= & -\frac{\mathrm{k}_{3} \mathrm{C}_{\mathrm{CH}_{3} \mathrm{OH} \text {,g.p. }}}{\mathrm{a}+\mathrm{bC}_{\mathrm{CH}_{3} \mathrm{OH}, \text { g.p. }}} .
\end{aligned}
$$

According to this equation, the order of the methanol oxidation with the corresponding values of the constants $\mathrm{a}, \mathrm{b}$ and $\mathrm{k}_{3}$ could be less than unity. Thus, this leads to a kinetic equation with a reduced order of the reaction of methanol.

It should be noted that similar equations for the rates of oxidation of methanol and formaldehyde on iron molybdate catalyst were first reported in refs. $[24,25]$, where the equations were simplified by substitution of the methanol concentration in the denominator by its initial value, therefore increasing the order of reaction to the unity. In kinetic equation proposed in this work, the first order requires the condition $\mathrm{a} \geq \mathrm{b}$ which is possible at a sufficiently high concentration of the adsorbed alcohol molecules. It is obvious that with decreasing concentrations of methanol in the reaction medium its content on the catalyst surface will be reduced, resulting in a change of the relationship between different forms of adsorption.

\section{Conclusions}

The adsorption properties of $\mathrm{Fe}_{2} \mathrm{O}_{3}, \mathrm{MoO}_{3}$ and $\mathrm{Fe}_{2}\left(\mathrm{MoO}_{4}\right)_{3}$ were studied at a temperature below the ignition temperature of the iron molybdate catalyst. 
The impossibility of the formation of oxygen radical particles on their surfaces at room temperature allows separating the adsorption processes from the chemical conversion processes. This approach is very useful for the determination of the mechanism of the increased catalytic activity of iron and molybdenum oxides mixture. It is known that the adsorption stage in a heterogeneous catalytic process determines the surface concentration of the converting substance, and thus can influence the rate of the overall process. Therefore, differences in the adsorption properties of $\mathrm{Fe}(\mathrm{III}), \mathrm{Mo}(\mathrm{VI})$ oxides and iron molybdate can be a principal cause of differences in their catalytic selectivity.

Based on the performed adsorption measurements, it was unequivocally shown that $\mathrm{Fe}(\mathrm{III})$ and $\mathrm{Mo}(\mathrm{VI})$ oxides more active adsorb the organic compounds with electron-donating heteroatoms than iron molybdate (III).

It could be supposed that this difference of the surface properties of individual oxides and their mixtures leads to different magnitudes of the surface concentrations (as well as to the different retention times on the surface) of formaldehyde, which is an intermediate product of methanol oxidation. Therefore, it becomes obvious that the higher the concentration and larger residing time on the surface, the higher is the probability of further oxidation of formaldehyde. This leads to the conclusion that if $\mathrm{Fe}(\mathrm{III})$ and $\mathrm{Mo}(\mathrm{VI})$ individual oxides are involved, the methanol oxidation process is characterized by lower selectivity due to the increased rate of formaldehyde oxidation to formic acid and then to carbon dioxide.

\section{Acknowledgements}

The work was supported by the USUCT State R\&D project 24/170290 and ICCCW NASU project III-6-16:20.

\section{REFERENCES}

1. Andersson A., Hernelind M., Augustsson O. A study of the ageing and deactivation phenomena occurring during operation of an iron molybdate catalyst in formaldehyde production // Catalysis Today. - 2006. - Vol.112. - P.40-44.

2. The calculation of the thermodynamic equilibrium in the system $\mathrm{Fe}^{3+} / \mathrm{MoO}_{4}{ }^{2-} / \mathrm{H}^{+}\left(\mathrm{OH}^{-}\right) / \mathrm{H}_{2} \mathrm{O}$ and determination of the reasonable conditions for the deposition of iron molybdate / N.V. Nikolenko, A.O. Kostynyuk, Y.V. Kalashnikov, E.A. Cheremis // Russian Journal of Applied Chemistry. - 2012. - Vol.85. No. 12. - P.1814-1819.

3. Chemical precipitation of iron(III) molybdate + molybdenum trioxide mixtures through continuous crystallization /
M.V. Nikolenko, A.O. Kostynyuk, F. Goutenoire, Yu.V. Kalashnikov // Inorganic Materials. - 2014. - Vol.50. - P.1140-1145.

4. Kinetics of the thermal treatment of an iron-molybdenum catalyst / Kostynyuk A.O., Gutenuar F., Kalashnikova A.N., Kalashnikov Yu.V., Nikolenko N.V. // Kinetics and Catalysis. 2014. - Vol.55. - No. 5. - P.649-655.

5. Origin of the synergistic interaction between $\mathrm{MoO}_{3}$ and iron molybdate for the selective oxidation of methanol to formaldehyde / Routray K., Zhou W., Kiely C.J., Grunert W., Wachs I.E. // Journal of Catalysis. - 2010. - Vol.275. - P.8498.

6. Bowker M. Rules for selective oxidation exemplified by methanol selective oxidation on iron molybdate catalysts // Topics in Catalysis. - 2015. - Vol.58. - P.606-612.

7. The role of the suprastoichiometric molybdenum during methanol to formaldehyde oxidation over Mo-Fe mixed oxides / A.P. Soares Dias, F. Montemor, M.F. Portela, A. Kiennemann // Journal of Molecular Catalysis A: Chemical. - 2015. - Vol.397. - P.93-98.

8. Adsorption of organic compounds from aqueous solutions on silica gel and alpha-aluminum oxide: A charge control model / Nikolenko N.V., Taran I.B., Plaksienko I.L., Vorob'ev N.K., Oleinik T.A. // Kolloidnyi Zhurnal. - 1999. - Vol.61. - No. 4. - P.488-491.

9. Nikolenko N.V. Surface properties of calcite: adsorption model with the orbital control // Adsorption Science and Technology. - 2001. - Vol.19. - No. 3. - P.237-244.

10. Nikolenko N.V., Esajenko E.E. Surface properties of synthetic calcium hydroxyapatite // Adsorption Science and Technology. - 2005. - Vol.23. - No. 7. - P.543-553.

11. Breeuwsma A., Lyklema J. Physical and chemical adsorption of ions in the electrical double layer on hematite $\left(\alpha-\mathrm{Fe}_{2} \mathrm{O}_{3}\right) / /$ Journal of Colloid and Interface Science. - 1973. Vol.43. - No. 2. - P.437-448.

12. Бибин В.Н., Попов Б.И. Кинетика окисления метанола воздухом на окисном железомолибденовом катализаторе // Кинетика и катализ. - 1969. - Т.10. - № 6. - С.13261335.

13. Kotok V., Kovalenko V., Malyshev V. Comparison of oxygen evolution parameters on different types of nickel hydroxide // Eastern European Journal of Enterprise Technologies. - 2018. - Vol.5. - № 12(89). - P.12-19.

14. Голодеи Г.И. Роль окислительно-восстановительных и кислотно-основных свойств поверхности окисных катализаторов в гетерогенном окислительном катализе // Теоретическая и экспериментальная химия. - 1982. - № 1. C. $37-45$.

15. Гагарин С.Г., Горшков А.П., Марголис Л.Я. Модель переходного состояния при каталитическом окислении альдегидов алифатического ряда // Кинетика и катализ. - 1972. - T.13. - № 1. - C.136-140.

Received 03.02.2019 


\section{РІЗНИЦЯ АДСОРБЦІЙНИХ ВЛАСТИВОСТЕЙ ОКСИДІВ Fе(III), Мо(VI) I МОЛІБДАТУ Fе(III) ЯК ПРИЧИНА ВИСОКОЇ СЕЛЕКТИВНОСТІ ОКИСНЕННЯ МЕТАНОЛУ НА ЗАЛІЗО-МОЛІБДЕНОВОМУ КАТАЛІЗАТОРІ \\ М.В. Ніколенко, Ю.В. Калашников, А.О. Костинюк, О.Ю. Полоз, С.В. Аксененко}

У статичних умовах при кімнатній температурі вивчена адсорбція низки органічних кислот і основ з водних і метанольних розчинів. Показано, що органічні сполуки адсорбуються на оксидах $\mathrm{Fe}(\mathrm{III})$ i Mo(VI) $і$ молібдаті $\mathrm{Fe}(\mathrm{III})$ за рахунок утворення поверхневих водневих зв 'язків. Можливість адсорбиї за допомогою донорно-акиепторної взаємодії органічних сполук з поверхневими катіонами $\mathrm{Fe}^{3+}$ не встановлена. Показано, що енергії адсорбції органічних основ лінійно корелюють з ефективним зарядом атомів Нітрогену, а їх адсорбційна здатність змінюеться в ряду: $\mathrm{Fe}_{2} \mathrm{O}_{3}>\mathrm{MoO}_{3}>\mathrm{Fe}_{2}\left(\mathrm{MoO}_{4}\right)_{3}$. Запропоновано пояснення цих кореляцій на основі концепцї̈ домінування електростатичних взаємодій. Гетерогенно-каталітичне окиснення метанолу та формальдегіду запропоновано розглядати в припущенні двох форм адсорбщї їх молекул: при зв'язуванні атомів Оксигену з кислотними центрами Льюїса або при взаємодії атомів Карбону $і$ Гідрогену зв'язків $\mathrm{C}-\mathrm{H}$ з основними иентрами Льюїса на поверхні каталізатора. Зроблено висновок, що селективність залізо-молібденового каталізатора при парціальному окисненні метанолу може бути обумовлена зниженою здатністю до адсорбиї на його поверхні проміжних продуктів реакції окиснення метанолу.

Ключові слова: адсорбція, ефективний заряд, молібден оксид, ферум оксид, ферум молібдат.

DIFFERENCE IN ADSORPTION PROPERTIES OF Fe(III), Mo(VI) OXIDES AND Fe(III) MOLYBDATE AS A CAUSE OF HIGH SELECTIVITY OF METHANOL OXIDATION ON IRON MOLYBDATE CATALYST

\author{
N.V. Nikolenko ${ }^{a}{ }^{*}$, Yu.V. Kalashnikov ${ }^{b}$, A.O. Kostyniuk ${ }^{c}$, \\ A.Yu. Poloz ${ }^{d}$, E.V. Aksenenko ${ }^{e}$
}

a Ukrainian State University of Chemical Technology, Dnipro, Ukraine

b Trespa International B.V., Weert, Netherlands

c National Institute of Chemistry, Ljubljana, Slovenia

d New Technologies Ltd., Dnipro, Ukraine

e Dumansky Institute of Colloid Chemistry and Water Chemistry, Kyiv, Ukraine

* e-mail: n_nikolenko@ukr.net

The adsorption of a number of organic acids and bases from aqueous and methanol solutions was studied under static conditions at room temperature. It was shown that the organic compounds are adsorbed on $\mathrm{Fe}(\mathrm{III})$ and $\mathrm{Mo}(\mathrm{VI})$ oxides and $\mathrm{Fe}(\mathrm{III})$ molybdate due to the formation of the surface hydrogen bonds. The possibility of the adsorption by means of a donor-acceptor interaction of the organic compounds with the surface cations $\mathrm{Fe}^{3+}$ was not detected. It was shown that the adsorption energies of organic bases are linearly correlated with the effective charge of nitrogen atoms and their adsorbability changes in the following range: $\mathrm{Fe}_{2} \mathrm{O}_{3}>\mathrm{MoO}_{3}>$ $>\mathrm{Fe}_{2}\left(\mathrm{MoO}_{4}\right)_{3}$. An explanation of these correlations was proposed based on the concept of the domination of electrostatic interactions. Heterogeneous-catalytic oxidation of methanol and formaldehyde was proposed to consider assuming two forms of adsorption of their molecules: via binding of oxygen atoms with Lewis acid sites, or via the interaction of carbon and hydrogen atoms of the $\mathrm{C}-\mathrm{H}$ bonds with Lewis basic centers of a catalyst. It was concluded that the selectivity of the iron molybdate catalyst in the partial oxidation of methanol can be caused by low adsorbability of intermediate products of the methanol oxidation reaction on the catalyst surface.

Keywords: adsorption; effective charge; molybdenum oxide; ferric oxide; iron molybdate.

\section{REFERENCES}

1. Andersson A., Hernelind M., Augustsson O. A study of the ageing and deactivation phenomena occurring during operation of an iron molybdate catalyst in formaldehyde production. Catalysis Today, 2006, vol. 112, pp. 40-44.

2. Nikolenko N.V., Kosynyuk A.O., Kalashnikov Yu.V., Cheremis E.A. The calculation of the thermodynamic equilibrium in $\mathrm{Fe}^{3+/} \mathrm{MoO}_{4}{ }^{2-} / \mathrm{H}^{+}\left(\mathrm{OH}^{-}\right) / \mathrm{H}_{2} \mathrm{O}$ system and determination of reasonable conditions for iron molybdate deposition. Russian Journal of Applied Chemistry, 2012, vol. 85, pp. 1814-1819.

3. Nikolenko M.V., Kostynyuk A.O., Goutenoire F., Kalashnikov Yu.V. Chemical precipitation of iron(III) molybdate + molybdenum trioxide mixtures through continuous crystallization. Inorganic Materials, 2014, vol. 50, pp. 1140-1145.

4. Kostynyuk A.O., Gutenuar F., Kalashnikova A.N., Kalashnikov Yu.V., Nikolenko N.V. Kinetics of the thermal treatment of an iron-molybdenum catalyst. Kinetics and Catalysis, 2014, vol. 55, pp. 649-655.

5. Routray K., Zhou W., Kiely C.J., Grunert W., Wachs I.E. Origin of the synergistic interaction between $\mathrm{MoO}_{3}$ and iron molybdate for the selective oxidation of methanol to formaldehyde. Journal of Catalysis, 2010, vol. 275, pp. 84-98.

6. Bowker M. Rules for selective oxidation exemplified by methanol selective oxidation on iron molybdate catalysts. Topics in Catalysis, 2015, vol. 58, pp. 606-612.

7. Soares Dias A.P., Montemor F., Portela M.F., Kiennemann A. The role of the suprastoichiometric molybdenum during methanol to formaldehyde oxidation over $\mathrm{Mo}-\mathrm{Fe}$ mixed oxides. Journal of Molecular Catalysis A: Chemical, 2015, vol. 397, pp. 93-98.

8. Nikolenko N.V., Taran I.B., Plaksienko I.L., Vorob'ev N.K., Oleinik T.A. Adsorption of organic compounds from aqueous solutions on silica gel and alpha-aluminum oxide: a charge control model. Colloid Journal, 1999, vol. 61, no. 4, pp. 488-491.

9. Nikolenko N.V. The surface properties of calcite: an adsorption model with the orbital control. Adsorption Science \& Technology, 2001, vol. 19, pp. 237-244.

10. Nikolenko N.V, Esajenko E.E. Surface properties of synthetic calcium hydroxyapatite. Adsorption Science \& Technology, 2005, vol. 23, pp. 543-553.

11. Breeuwsma A., Lyklema J. Physical and chemical adsorption of ions in the electrical double layer on hematite $\left(\alpha-\mathrm{Fe}_{2} \mathrm{O}_{3}\right)$. Journal of Colloid and Interface Science, 1973, vol. 43, pp. 437-448.

12. Bibin V.N., Popov B.I. Kinetika okisleniya metanola vozdukhom na okisnom zhelezomolibdenovom katalizatore [The kinetics of methanol oxidation by air on the oxide ironmolybdenum catalyst]. Kinetika $i$ Kataliz, 1969, vol. 10, no. 6, pp. 1326-1335. (in Russian). 
13. Kotok V., Kovalenko V., Malyshev V. Comparison of oxygen evolution parameters on different types of nickel hydroxide. Eastern European Journal of Enterprise Technologies, 2018, vol. 5, no. 12(89), pp. 12-19.

14. Golodets G.I. Rol' okislitel'no-vosstanovitel'nykh i kislotno-osnovnykh svoistv poverkhnosti okisnykh katalizatorov $\mathrm{v}$ geterogennom okislitel'nom katalize [The role of redox and acid-base properties of the surface of oxide catalysts in the heterogeneous oxidizing catalysis]. Teoreticheskaya $i$ Eksperimental'naya Khimiya, 1982, no. 1, pp. 37-45. (in Russian).

15. Gagarin S.G., Gorshkov A.P., Margolis L.Ya. Model' perekhodnogo sostoyaniya pri kataliticheskom okislenii al'degidov alifaticheskogo ryada [The model of transition sate in the catalytic oxidation of aliphatic aldehydes]. Kinetika $i$ Kataliz, 1972, vol. 13, no. 1, pp. 136-140. (in Russian). 